DOI https://doi.org/10.30525/978-9934-26-073-5-2-49

\title{
ВИВЧЕННЯ ПІДРЯДНИХ СЛОВОСПОЛУЧЕНЬ У ЗВО
}

\author{
Чубань Т. В. \\ кандидат філологічних наук, доцент, \\ дочент кафедри української лінгвістики та методики навчання \\ Університету Григорія Сковороди у Переяславі \\ Кардаш Л. В. \\ кандидат філологічних наук, доцент, \\ доцент кафедри украӥнської лінгвістики та методики навчання \\ Університету Григорія Сковороди у Переяславі \\ м. Переяслав, Київська область, Украӥна
}

Синтаксису сучасної української мови належить особливе місце серед дисциплін, які формують лінгвістичне мислення студентів-філологів. Викладання синтаксичної теорії відповідно до сучасного етапу іiі розвитку, прилучення студентів до досягнень лінгвістичної думки завдання, яке потребує певного забезпечення: наявності підручників, навчальних та навчально-методичних посібників. Створення підручників та навчальних посібників 3 синтаксису сучасної української мови усвідомлене як першорядне завдання української лінгвістики. Проте практика вивчення теоретичного курсу, а також проведення практичних i семінарських занять, переконують у тому, що творче застосування матеріалу можливе за умови аналізу різних підходів до кожної проблеми, різних бачень того чи іншого явища, бо це привчає співставляти $\mathrm{i}$ аналізувати. Теоретичний матеріал викладачі та студенти черпають 3 наукових праць і навчальних посібників, які представляють найновіші здобутки галузі лінгвістичних знань.

На сьогоднішній день до вузівських підручників поставлено нові вимоги: у текстах студенти серед запланованого програмою матеріалу повинні віднайти і систематизувати необхідне, самостійно опрацювавши певні положення розділу 3 мови. Тому актуальними $є$ рекомендації Міністерства освіти і науки України щодо збільшення кількості годин на самостійну роботу студентів, що зобов'язує, викладачів розробити i систематизувати самостійні завдання, темарії рефератів. Характерною особливістю самостійної роботи студентів, яка включає пошук знань, формування уміння аналізу, узагальнення отриманої інформації, 
запам'ятовування певних положень, є уміння використати цю суму знань на практиці.

У сучасній українській мовознавчій науці чільне місце посідають праці, які присвячено проблемам синтаксису (Д. Х. Баранник, С. П. Бевзенко, .Р.Вихованець, К. Г. Городенська, В. Д. Горяний, А. П. Грищенко, П. С. Дудик, Н. Л. Іваницька, А. Г. Кващук, О.С.Мельничук, К. М. Плиско, І. І. Слинько, К. Ф. Шульжук та ін.).

Вивчення одиниць синтаксису ефективно здійснювати за модульною технологією. Пропонуємо розділити весь матеріал на три модулі: М - I «Словосполучення. Особливості словосполучень», М - II «Просте речення», М - III «Складне речення. Текст». Модульну програму курсу розроблено так, що кожен модуль включає змістову частину. Структурними компонентами програми $\epsilon$ умови оцінювання, вимоги до знань студентів, критерії до підсумкового контролю. Ефективне вивчення матеріалу залежить від діяльності і викладача, i студента. До функцій викладача належать: проведення на високому якісному рівні лекцій, підготовка і проведення практичних і лабораторних занять, перевірка письмових робіт, індивідуальне і групове консультування. Організація діяльності студентів спрямована на оволодіння сумою знань про три синтаксичні одиниці: словосполучення, речення $\mathrm{i}$ текст. Особливої уваги заслуговують дослідження синтаксичної одиниціконструкції - словосполучення.

Відповідно до положень традиційної граматики, в основу поділу словосполучень на підрядні і словосполучення сурядні покладено синтаксичний зв'язок. Дотепер у мовознавчій літературі немає єдиної думки щодо оцінки сполучень слів, поєднаних між собою сурядним зв'язком (Д. Баранник, О. Мельничук). Компоненти підрядних словосполучень пов'язані прислівним підрядним зв'язком. Ці словосполучення утворюються шляхом поєднання двох мінімальних одиниць, одна 3 яких виконує роль головного члена, а друга - залежного.

Складовими формально-синтаксичної характеристики підрядного словосполучення $\epsilon: 1)$ визначення групи підрядного словосполучення за способом підрядного зв'язку між компонентами; 2) характеристика підрядного словосполучення відносно його будови; 3) визначення різновиду підрядного словосполучення за категоріально-морфологічним характером головного члена.

В академічній граматиці виділяють три основні способи підрядного зв'язку (узгодження, керування, прилягання) і два неосновні (підрядносполучникове підпорядкування, тяжіння). При узгодженні форми відмінка, числа і роду (чи одного з них) або особи залежного члена 
уподібнюються до відповідних форм головного члена. Наприклад: diм високий, дівчина красива. Студентам обов'язково наголошується про можливість повного і неповного узгодження.

У словосполученнях, компоненти яких пов'язані способом керування, головний член вимагає від залежного відповідної відмінкової форми. Синтаксичний зв'язок керування можливий лише у словосполученнях, у яких залежний член $є$ представником іменної частини мови. Наприклад: чуйна до товаришів, написати текст.

У словосполученнях, компоненти яких пов'язані зв'язком прилягання, залежний член - повнозначне слово, яке позбавлене форм словозміни (прислівник, дієприслівник, інфінітив). Наприклад: співати тихо, майстер вичивати.

Підрядносполучниковим підпорядкуванням зветься такий тип синтаксичного зв'язку, при якому за допомогою підрядного сполучника залежний член приєднується до ведучого. Наприклад: мaлi, як $i$ cmapi; злий, бо самотній.

Є особливий різновид підрядного зв'язку, який називається тяжінням. Суть його полягає в тому, що залежне слово, що стоїть після присудка i підпорядковується йому, семантично тяжіє до підмета і пояснює його.

Словосполучення, як синтаксичні одиниці-конструкції, що утворені сполученням двох або кількох повнозначних слів, за будовою класифікуються на прості і складні. 3 розвитком функціонального синтаксису, зокрема у працях I. Р. Вихованця, щодо будови, словосполучення розділяють на два типи: словосполучення елементарні, які складаються 3 двох компонентів, і словосполучення неелементарні, які складаються 3 трьох і більше компонентів.

Підрядні словосполучення в залежності від морфологічної природи ведучих слів класифікуються на шість різновидів: субстантивні, ад'єктивні, прономінальні, нумеральні, адвербіальні, вербальні. Відповідно до чотирьох частиномовних різновидів гетерогенної класифікації частин мови розрізняють словосполучення іменникові, прикметникові, прислівникові, дієслівні.

У процесі вивчення синтаксису у ЗВО і в $33 \mathrm{CO}$ студенти та учні повинні засвоїти положення, що пов'язані з описом формальних типів підрядних словосполучень, елементарності/неелементарності їх будови та різновидів за категоріально-морфологічним характером головного члена. Загальній структурі підрядного словосполучення властиві семантико-синтаксичні відношення, які виникають між компонентами словосполучення. 